\title{
“TIPS AND TRICK” BAHASA INGGRIS DALAM MENYELESAIKAN SOAL DI MTS WALI AMINAH NGORO JOMBANG
}

\author{
"Tips And Trick" English In Completing Problems In Mts Wali Aminah Ngoro \\ Jombang
}

\author{
I'in Noviana \\ STIKES PEMKAB JOMBANG \\ E-Mail: ienrahmat@yahoo.com
}

\begin{abstract}
ABSTRAK
Bahasa Inggris adalah bahasa internasional yang menghubungkan orang-orang di seluruh dunia. Bahasa inggris menjadi bahasa resmi yang dipakai dan disahkan oleh PBB. Agar dapat melakukan komunikasi dengan orang-orang yang berbeda latar belakang budaya dan kenegaraan, bahasa Inggris menjadi pilihan utama yang sering dipakai dalam melakukan komunikasi. Kemampuan berbahasa inggris disekolah ini kurang mendapat perhatian yang signifikan dengan alasan bahasa inggris yang susah untuk dipelajari dari segi kosa kata dan pengucapan yang berbeda dengan tulisan nya.

Tujuan dari kegiatan ini adalah untuk mengambangkan kemampuan anak dalam memelajari bahasa inggris dimulai dari mempelajari kosa kata yang paling mudah. Sehingga anak akan mudah mempelajari bahasa inggris dan tertarik dalam menggunakan bahasa inggris untuk kehidupan sehari - hari nya.

Hasil dari kegiatan ini adalah video media dapat digunakan untuk membantu meningkatkan kemampuan bahasa inggris anak, dengan video yang diputar akan memudahkan anak untuk mengingat kosa kata yang sedang diputar. Sebelum diputarkan video, anak - anak diberikan contoh kata - kata (vocabularies) yang kemudian diajarkan cara pengucapan dan artinya. Video ini efektif dalam meningkatkan kemampuan anak dalam belajar bahasa inggris.
\end{abstract}

Kata Kunci: Bahasa Inggris, Tips and Trick

\section{PENDAHULUAN}

Bahasa menjadi alat komunikasi yang terpenting. karenanya, bahasa mempunyai peran sentral yang sangat penting dalam perkembang-an intelektual, sosial, dan budaya. Bahasa inggris merupakan bahasa asing yang ada di Negara kita dan mempunyai peran yang sangat penting guna meningkatkan kemampuan berbahasa anak dan membantu memahami saat berkomunkasi dengan orang asing. Dengan peranannya yang sangat besar, Bahasa Inggris menjadi penunjang keberhasilan dalam mempelajari semua bidang studi. Manfaat Bahasa Inggris bagi siswa dalam pembelajaran bahasa diharapkan membantu siswa mengenal dirinya, budaya sendiri dan budaya asing, mengemukakan gagasan dan perasaan, berpartisipasi dalam masyarakat satu bahasa, dan menggunakan kemampuan analitis dan imajinatif yang ada dalam dirinya.

Bahasa Inggris adalah bahasa internasional yang menghubungkan orangorang di seluruh dunia. Bahasa inggri menjadi bahasa resmi yang dipakai dan disahkan oleh PBB. Agar dapat melakukan komunikasi dengan orang-orang yang berbeda latar belakang budaya dan kenegaraan, bahasa Inggris menjadi pilihan utama yang sering dipakai dalam melakukan komunikasi. Selain itu, informasi yang ada di dunia ini kebanyakan diterbitkan dalam bahasa Inggris, dimulai dari buku-buku yang banyak diterbitkan dalam bahasa Inggris, baik buku ilmiah, jurnal, artikel, atau bahasa pada website di dunia internet. Ketrampilan berbahasa Inggris yang dikuasai oleh seseorang akan membantu dia untuk mengakses hal-hal yang selama ini tidak ada di dalam bacaan- bacaan yang terbit di Indonesia. Karena itu, kemampuan berbahasa Inggris akan memudahkan orang Indonesia untuk mengembangkan wawasan pengetahuannya dengan memberikan akses pada pengetahuan yang ada di luar Indonesia.

Didalam proses pembelajaran bahasa 
Inggris, komponen yang paling dominan adalah sumber belajar bahasa Inggris (learning resources), metode mengajar bahasa Inggris (teaching method), materi dan proses pembelajaran (teaching materials and process), sikap dan orientasi guru dalam mengajar (teachers' attitude and orientation), sikap dan suasana hati siswa (students' attitude and mood), fasilitas pembelajaran (learning facilities), dan kurikulum serta silabus (curriculum and syllabus). Semua faktor di atas saling berhubungan menjadi satu system yang saling tergantung dan mendukung satu sama lain. Kelemahan satu faktor akan mengimbas ke faktor yang lainnya. Keterkaitan antar bagian system itu bermuara pada keberhasilan pembelajaran bahasa Inggris. Indikator keberhasilan belajar siswa diukur dari seberapa jauh mereka mampu berkomunikasi dalam bahasa Inggris secara lisan dan tertulis.

Pembelajaran bahasa inggris bisa diberikan saat anak masih menempuh pendidikan sekolah dasar, dengan memberikan sedikit pengetahuan anak tentang bahasa asing akan memudahkan dia saat belajar bahasa asing di sekolah menengah pertama. Dalam kurikulum baru, bahasa inggris sudah mulai diajarkan saar anak duduk di bangku kelas 1 SD dengan memasukkan bahasa inggris ke dalam materi tambahan (ekstrakulikuler). Disini, siswa memperoleh pengetahuan tentang kata - kata dasar dalam bahasa inggris. dalam hal ini penulis mencoba untuk melakukan pengabdian masyarakat di SDN Badang II Ngoro Jombang.

SDN Badang II ini terletak di desa badang kecamatan Ngoro Kabupaten Jombang, siswa di sekolah ini banyak didominasi oleh masyarakat menengah kebawah yang tidak mampu untuk menyekolahkan anak mereka dengan biaya yang lebih besar. Tetapi kualitas yang diberikan oleh sekolah ini juga tidak kalah bagus dengan sekolah swasta yang ada dijombang. Kemampuan berbahasa inggris disekolah ini kurang mendapat perhatian yang signifikan dengan alasan bahasa inggris yang susah untuk dipelajari dari segi kosa kata dan pengucapan yang berbeda dengan tulisan nya. Pelaksana memberikan gambar dalam meningkatkan kemampuan berbahasa inggris siswa, untuk meningkatkan kosa kata (vocabularies).

\section{METODE PELAKSANAAN}

Kegiatan pengabdian masyarakat dalam peningkatan kemampuan berbahasa inggris anak dengan menggunakan video media yang dilaksanakan pada tanggal 17 mei 2017. Kegiatan ini dilakukan guna meningkatkan minat belajar bahasa inggris anak yang dimulai dari tingkat dasar. Kegiatan yang dilakukan dengan melalui 3 tahap, antara lain:

Kegiatan pendahuluan: (30 menit)

- Peserta masuk keruang kelas

- Peserta mengisi daftar hadir

- Perkenalan antara pelaksana dan peserta

- Stimulasi atau brainstorming Kegiatan inti: (70 menit)

- Stimulasi tentang Bahasa Inggris

- Penyuluhan tentang Bahasa Inggris berupa video

- Penerapan tentang pembelajaran Bahasa Inggris dengan video song

- Pemberian hadiah kepada peserta yang menang dalam games Bahasa Inggris

- Hadiah berupa bahan bacaan bahasa inggris (buku,kamus atau majalah Bahasa Inggris)

- Feedback/ umpan balik atas manfaat pembelajaran Bahasa Inggris dengan menggunakan bacaan/ teks Kegiatan penutup: (20 menit)

- Mengulas kembali pembelajaran bahasa inggris dengan meningkatkan kosa kata (vocabularies) dalam lagu.

- Memberikan catatan kecil tentang kosa kata Bahasa Inggris

- Penutup/ pembacaan doa dan salam

\section{HASIL DAN PEMBAHASAN}

Kegiatan pengabdian masyarakat ini dilaksanakan di SDN Badang II Ngoro pada tanggal 17 Mei 2017 pukul 09.00 WIB yang diikuti oleh 40 peserta siswa SDN Badang II Ngoro Jombang. Kegiatan diawali dengan pembukaan yang diisi oleh pelaksana dan Kepala Sekolah, pemaparan materi dan Evaluasi.

Sasaran kegiatan pengabdian masyarakat adalah siswa/ siswi yang ada di kelas 4 dan 5 SDN Badang II Ngoro Jombang yang ada di desa Badang Kecamatan Ngoro.

Kegiatan pengajaran peningkatan kemampuan bahasa inggris ini dilakukan 
untuk membiasakan siswa/ siswi untuk berbicara atau menyukai bahasa inggris sejak dini. Antusiasme peserta jelas terlihat dari ketertarikan mereka dalam mengikuti dan memperhatikan bagaimana bahasa inggris itu harus diucapkan, dengan pengucapan yang berbeda dari tulisan nya. Menurut Jack C. Richard (2008:2) mengungkapkan bahwa speaking adalah kegiatan mengulang atas apa yang didengar, menghafalkan dialogue atau latihan secara rutin (drilling). Dalam berlatih berbicara (speaking) banyak masalah yang dihadapi oleh siswa ketika memulai untuk praktek berbicara bahasa inggris. Karena bahasa inggris bukan merupakan bahasa ibu dinegara kita dan itu hanya sebagai bahasa asing dimana bahasa ibu adalah bahasa daerah, bahasa pertama atau utamanya adalah bahasa Indonesia, jadi sangat sulit bagi mereka yang bukan merupakan penutur bahasa asing untuk belajar bahasa inggris.

Sedangkan untuk pengertian Video Media adalah menurut Sri Anitah (2010: 5) menjelaskan pula bahwa media adalah grafik, fotografi, elektronik, atau alat-alat mekanik untuk menyajikan, memproses, dan menjelaskan informasi lisan atau visual. Sedangkan menurut Smaldino, dkk (2008) dalam buku Sri Anitah (2010: 8) mengatakan bahwa media adalah suatu alat komunikasi dan sumber informasi. Dikatakan media pembelajaran, bila segala sesuatu tersebut membawa pesan untuk suatu tujuan pembelajaran. Untuk melatih kemampuan berbicara mahasiswa beberapa bahan bisa digunakan untuk menarik minat mahasiswa dalam berbicara bahasa inggris, salah satunya adalah media video.

Jadi dalam kegiatan pengabdian ini, pelaksana membuat pembelajaran yang menyenangkan dengan menggunakan video media sebagai sarana untuk meningkatkan ketertarikan siswa dalam belajar Bahasa Inggris.

\section{KESIMPULAN}

1. Peningkatkan kemampuan Bahasa Inggris anak sangat diperlukan guna memudahkan mereka dalam mempelajari kemampuan Bahasa di tingkat sekolah yang lebih tinggi.

2. Peningkatan kemampuan berbahasa Inggris ini bisa menggunakan Video Media sebagai sarana untuk menarik ketertarikan siswa

Saran untuk pengabdian masyarakat ini adalah diperlukan dukungan dari pihak sekolah untuk memberikan tambahan (ekstrakulikuler) bahasa inggris sehingga akan lebih mudah mengajari kemampuan bahasa sejak dini.

\section{DAFTAR PUSTAKA}

Richard, Jack C. 2008. Teaching listening and speaking. New York. Cambridge university press

Brown, H. Douglas. 2007. Principles of Language Learning and Teaching, fifth Edition. New York: Pearson Education, Inc.

Sri Anitah. 2010. Media pembelajaran. Surakarta.Yuma Pustaka bekerja sama dengan FKIP UNS 